\title{
Prevalence and determinants of hypertension in MBBS students of Govt. Medical College, Kannauj, Uttar Pradesh
}

\author{
Tanu Midha ${ }^{1, *}$, Seema Nigam², D.S. Martolia ${ }^{3}$, Samarjeet Kaur ${ }^{4}$ \\ ${ }^{\mathbf{1}}$ Associate Professor, Dept. of Community Medicine, Government Medical College Kannauj, Uttar Pradesh, ${ }^{2}$ Professor and Head, \\ Dept. of Community Medicine, GSVM Medical College Kanpur, Uttar Pradesh, ${ }^{3}$ Professor and Head, Dept. of Community \\ Medicine, Government Medical College Kannauj, Uttar Pradesh, ${ }^{4}$ Lecturer, Dept. of Community Medicine, GSVM Medical \\ College Kanpur, Uttar Pradesh, India \\ *Corresponding Author: \\ Email: tanumidha2001@gmail.com
}

\begin{abstract}
Introduction: Hypertension or increased blood pressure is a major public health problem in India. Medical students are very susceptible to hypertension.

Objectives: 1) To estimate the prevalence of hypertension among medical students. 2) To identify the determinants of hypertension.

Materials and Methods: It was a cross-sectional study done among the students of Govt. Medical College Kannauj. A total of 558 subjects, aged 17 to 21 years, 305 boys and 253 girls were included. Statistical analysis was done using Chi-square test and multiple logistic regression.

Results: Prevalence of hypertension among medical students was $18.5 \%$. A significant association of hypertension with males $(\mathrm{OR}=0.328)$, family history of hypertension $(\mathrm{OR}=2.812)$ level of physical activity $(\mathrm{OR}=0.395)$ and $\mathrm{BMI}(\mathrm{OR}=3.710)$ and academic performance $(\mathrm{OR}=2.611)$ was observed.

Conclusions: A high prevalence of hypertension was found among medical students. BMI and physical activity are the modifiable factors associated with hypertension which can be addressed to reduce the magnitude of hypertension in this study group.
\end{abstract}

Keywords: hypertension, BMI, Physical activity.

\section{Introduction}

The prevalence of hypertension among adults aged more than 25 years, in the world, was approximately $40 \%$ in the year 2008. The total population with uncontrolled blood pressure increased from 600 million in 1980 to nearly 1 billion in $2008 .^{1}$

Hypertension has been proved to cause mortality in 7.5 million of the total world population, around $12.8 \%$ of total mortality and approximately 57 million disability adjusted life years (DALYS) or 3.7\% of total DALYS. Increased blood pressure is a major contributor of coronary heart disease, ischemic and hemorrhagic stroke. The chances of cardiovascular disease double for each increment of $20 / 10 \mathrm{mmHg}$ of blood pressure. ${ }^{1}$ Cardiac failure, peripheral vascular disease, renal morbidity, retinal hemorrhage and ophthalmic morbidity are also consequences of hypertension. Proper treatment of hypertension is known to cause a reduction in all these complications.

WHO revealed that in 2008, prevalence of hypertension in the Indian population was $32.5 \%$ $(33.2 \%$ in males and $31.7 \%$ in females). ${ }^{2}$ Approximately, $25.6 \%$ of treated patients had controlled blood pressure. In 2014, meta analysis was conducted which showed that around $33 \%$ of the urban and $25 \%$ of the rural Indian population was found to suffer from hypertension. ${ }^{3}$ Among these, approximately $25 \%$ of the rural population and $42 \%$ of the urban population had awareness of their increased blood pressure. Around $25 \%$ of the rural population and
$38 \%$ of the urban population was under treatment for raised blood pressure. About 1/10th of the rural and $1 / 5$ th of the urban population with hypertension had controlled blood pressure. Very scarce data regarding raised blood pressure and its associated factors are available from India.

Medical students are prone to stress and have unhealthy lifestyles, so they are susceptible to hypertension. Since hypertension is a major problem in India and medical students are a vulnerable group, this study was done to estimate the prevalence and determinants of hypertension among medical students.

\section{Methodology}

A cross-sectional study was done in Govt. Medical College, Kannauj from October 2017 to February 2018. All students who were present on the day of the interview and willing to participate were involved. Informed consent was taken in writing. Ethical clearance was obtained from the Institutional Ethics Committee. The data was analyzed for 558 subjects. Among the study subjects there were 305 males and 253 females, in the age group between 17 and 21 years.

Data was recorded on a pre-designed and pre-tested questionnaire and data was collected regarding the following variables: age, socioeconomic status, family history of hypertension, physical activity, dietary pattern, weight, height, and BMI. Subjects were classified as using the diagnostic criteria of the American Heart Association (AHA) 2017: 


\begin{tabular}{|l|c|c|}
\hline Classification & $\begin{array}{c}\text { Systolic } \\
(\mathbf{m m H g})\end{array}$ & $\begin{array}{c}\text { Diastolic } \\
(\mathbf{m m H g})\end{array}$ \\
\hline Normal & $<120$ & $<80$ \\
\hline Elevated & $120-129$ & $<80$ \\
\hline Stage 1 & $130-139$ & $80-89$ \\
\hline Stage 2 & $\geq 140$ or & $\geq 90$ \\
\hline
\end{tabular}

Weight was measured while the subject was made to stand on Krup's weighing machine (least count $0.5 \mathrm{~kg}$ ). The scale was calibrated to zero before every reading. To measure height, the subject was made to stand in vertically against a hard surface, with the head positioned so that the top margin of the external auditory canal was in continuation with the lower margin of orbit. A hardboard was held vertical to the wall, just over the head, height was marked on the wall and was measured with a measuring tape (least count $0.5 \mathrm{~cm})$. Academic performance was considered as having good academic performance if his aggregate marks in the last professional examination were greater than or equal to $60 \%$. Physical activity was estimated as increments in BMR. Subject's BMR factor was estimated by recording the type of activity and time spent in every activity during the previous day. Level of activity was taken as sedentary, moderate or heavy, in terms of BMR in the following multiples:

\begin{tabular}{|l|c|c|c|}
\hline Gender & Sedentary & Moderate & Heavy \\
\hline Boys & 1.55 & 1.78 & 2.10 \\
\hline Girls & 1.55 & 1.64 & 1.82 \\
\hline
\end{tabular}

Data analysis was done using SPSS 20.0. Categorical variables were assessed using percentages and Chi square test. Multiple logistic regression analysis was conducted to analyse the association of factors with hypertension. $\mathrm{P}$ value $<0.05$ was taken as significant.

\section{Result}

There was a total of 558 subjects, 305 males and 253 females. Prevalence of hypertension was calculated as $18.5 \%$. (Table 1)
There was an association of hypertension with gender which was statistically significant $(\mathrm{P}<0.0001)$ as shown in Table 2. Prevalence was higher among males $(27.5 \%)$ in comparison to females $(7.5 \%)$. Hypertension was associated significantly with family history of hypertension $(\mathrm{P}<0.001)$ and $\operatorname{diet}(\mathrm{P}=0.019)$.

A significant association of hypertension was seen with level of physical activity $(\mathrm{P}=0.002)$. Hypertension prevalence was least among subjects with heavy activity (1.9\%), and was maximum among subjects with a sedentary activity (21.4\%). (Table 3) A significant association was found between hypertension and BMI $(\mathrm{P}=0.027)$. Around $24.8 \%$ of subjects with BMI greater than or equal to $25 \mathrm{~kg} / \mathrm{m}^{2}$ were hypertensive as compared to $16.3 \%$ subjects with BMI less than $25 \mathrm{~kg} / \mathrm{m}^{2}$. The association of hypertension and academic performance was also found to be significant (33.5\% among students with good performance and $12.0 \%$ among students with average performance). No association was observed between hypertension and type of family and hours of sleep.

Multiple logistic regression analysis showed that gender, family history of hypertension, BMI and academic performance were associated with hypertension and the association was found to be significant. Females were 0.328 times less likely to have hypertension as compared to males. Students whose family history of hypertension was positive were 2.812 times at risk of having hypertension as compared to those with a negative history. A $1 \mathrm{~kg} / \mathrm{m}^{2}$ rise in BMI was associated with a 3.710 times higher chance of hypertension (Table 4).

\section{Table 1: Classification of blood pressure among study subjects}

\begin{tabular}{|l|c|c|}
\hline $\begin{array}{c}\text { Blood Pressure } \\
\text { classification }\end{array}$ & No. & $\begin{array}{c}\text { Percentag } \\
\text { e }\end{array}$ \\
\hline Normal & 339 & 60.8 \\
\hline Elevated & 116 & 20.7 \\
\hline Stage 1 & 91 & 16.3 \\
\hline Stage 2 & 12 & 2.2 \\
\hline
\end{tabular}

Table 2: Biosocial correlates of hypertension

\begin{tabular}{|c|c|c|c|c|c|c|}
\hline \multirow{2}{*}{$\begin{array}{c}\text { Biosocial } \\
\text { Correlates }\end{array}$} & \multicolumn{2}{|c|}{ Hypertensive(n=103) } & \multicolumn{2}{|c|}{ Non-hypertensive( $(n=455)$} & \multirow[t]{2}{*}{ Total } & \multirow[t]{2}{*}{$P$ value } \\
\hline & No. & $\%$ & No. & $\%$ & & \\
\hline \multicolumn{7}{|c|}{ Type of family } \\
\hline Nuclear & 49 & 19.4 & 203 & 80.6 & 252 & \multirow[t]{2}{*}{0.586} \\
\hline Joint & 54 & 17.6 & 252 & 82.4 & 306 & \\
\hline \multicolumn{7}{|l|}{ Gender } \\
\hline Male & 84 & 27.5 & 221 & 72.5 & 305 & \multirow[t]{2}{*}{$<0.0001^{*}$} \\
\hline Female & 19 & 7.5 & 234 & 92.5 & 253 & \\
\hline \multicolumn{7}{|c|}{ Family History of hypertension } \\
\hline Present & 91 & 34.9 & 170 & 65.1 & 261 & \multirow{2}{*}{$<0.0001^{*}$} \\
\hline Absent & 12 & 4 & 285 & 96 & 297 & \\
\hline
\end{tabular}




\begin{tabular}{|l|c|c|c|c|c|c|}
\hline Vegetarian & 46 & 15 & 261 & 85 & 307 & $0.019 *$ \\
\hline Mixed & 57 & 22.7 & 194 & 78.3 & 251 & \\
\hline
\end{tabular}

$* \mathrm{P}$ value $<0.05$ is significant

Table 3: Determinants of hypertension

\begin{tabular}{|c|c|c|c|c|c|c|}
\hline \multirow[t]{2}{*}{ Determinants } & \multicolumn{2}{|c|}{ Hypertensive(n=103) } & \multicolumn{2}{|c|}{ Non-hypertensive $(n=455)$} & \multirow{2}{*}{ Total } & \multirow{2}{*}{ P value } \\
\hline & No. & $\%$ & No. & $\%$ & & \\
\hline \multicolumn{7}{|l|}{ Physical activity } \\
\hline Sedentary & 87 & 21.5 & 318 & 78.5 & 405 & \multirow[t]{3}{*}{$0.002 *$} \\
\hline Moderate & 15 & 14.9 & 86 & 85.1 & 101 & \\
\hline Heavy & 1 & 1.9 & 51 & 98.1 & 52 & \\
\hline \multicolumn{7}{|l|}{ BMI } \\
\hline$>25$ & 34 & 24.8 & 103 & 75.2 & 137 & \multirow[t]{2}{*}{$0.027 *$} \\
\hline$<25$ & 69 & 16.4 & 352 & 83.6 & 421 & \\
\hline \multicolumn{7}{|l|}{ Duration of sleep } \\
\hline$>8$ hours & 50 & 16.3 & 257 & 83.7 & 307 & \multirow[t]{2}{*}{0.144} \\
\hline$<8$ hours & 53 & 21.1 & 198 & 78.9 & 251 & \\
\hline \multicolumn{7}{|c|}{ Academic performance } \\
\hline Good & 56 & 33.5 & 111 & 66.5 & 167 & \multirow[t]{2}{*}{$<0.0001^{*}$} \\
\hline Average & 47 & 12 & 344 & 88 & 391 & \\
\hline
\end{tabular}

$* \mathrm{P}$ value $<0.05$ is significant

Table 4: Association of determinants with hypertension using multiple logistic

\begin{tabular}{|l|l|l|l|l|}
\hline Determinant & Odds ratio & Lower limit & Upper limit & P value \\
\hline Gender(Ref =Male) & 0.328 & 0.145 & 0.765 & $0.008^{*}$ \\
\hline $\begin{array}{l}\text { Family history of } \\
\text { hypertension } \\
\text { (Ref=Family } \\
\text { History Absent) }\end{array}$ & 2.812 & 1.745 & 4.891 & $<0.01^{*}$ \\
\hline Diet(Ref=Mixed) & 0.777 & 0.355 & 1.745 & 0.556 \\
\hline $\begin{array}{l}\text { Physical activity } \\
\text { (Ref = Sedentary) }\end{array}$ & 0.395 & 0.166 & 0.945 & $0.037^{*}$ \\
\hline BMI (per 1 kg/m2) & 3.710 & 2.626 & 6.100 & $<0.001^{*}$ \\
\hline $\begin{array}{l}\text { Academic } \\
\text { Performance } \\
\text { Ref=Average) }\end{array}$ & 2.611 & 1.562 & 5.125 & $<0.001^{*}$ \\
\hline
\end{tabular}

$* \mathrm{P}$ value $<0.05$ is significant

\section{Discussion}

In our study, the overall prevalence of hypertension was $18.5 \%$. Prevalence of hypertension was $27.5 \%$ in males and $7.5 \%$ in females. Our findings are similar to those of Chakraborty et al who observed a prevalence of hypertension of $17.6 \%$ in the Indian population. ${ }^{4}$ Gupta et al (33.4\%), Shanthirani et al (21.1\%), Anand(34.0\%), and in the early 2000s, and Reddy et al (27.7\%), Mohan et al (20.0\%), Midha et al (32.8\%) and Kaur et al(27.2\%), in the later years have shown that hypertension prevalence in the Indian population was ranging from $20 \%$ to $40 \%$. $^{4-11}$

The prevalence of hypertension among the medical students was high and comparable to the prevalence among the urban population because the stress due to academics and examination pressure among students are similar to stress occurring due to modern urban lifestyle which leads to hypertension. In this study, an association was found between academic performance and hypertension which shows that mental stress due to peer pressure and parental pressure increases the risk of hypertension.

In our study, there was a significant association between gender and hypertension. The prevalence of hypertension was higher in males $(27.5 \%)$ as compared to females $(7.5 \%)$. In a study from Varanasi, similar findings were observed and the prevalence of hypertension was significantly higher in males $(40.9 \%)$ as compared to females $(26.0 \%) .{ }^{12}$ The present study reveals that level of physical activity $(\mathrm{OR}=0.395)$ and BMI $(\mathrm{OR}=3.710)$ were significantly associated with hypertension. In the study from Varanasi also, the odds of hypertension in subjects with obesity $(\mathrm{OR}=3.57)$ was significanlty higher than in normal subjects. ${ }^{12}$ Similar association of hypertension with physical activity, and BMI was seen in a study done in Shimla. ${ }^{13}$ A study from China also reported that there was a significant 
association of hypertension with gender and BMI. Association of hypertension with physical activity, and BMI has been observed in several previous studies in the Indian population. ${ }^{14}$ The present study also revealed that there was a significant association between hypertension and diet and family history of hypertension. Shanthirani et al and Gupta R et al also observed a similar association. ${ }^{9,13}$

In conclusion, the present study reveals a high prevalence of hypertension among medical students. The non-modifiable risk factors of hypertension among medical graduates are gender and family history of hypertension, whereas the modifiable risk factors are BMI and physical activity, and these are similar to those in the general population. In addition, good academic performance is also a factor significantly associated with hypertension among medical students.

\section{References}

1. http://www.who.int/gho/ncd/risk_factors/blood_pressure_ prevalence_text/en/

2. Noncommunicable diseases country profiles 2011. http://www.who.int/nmh/countries/ind_en.pdf[Acc essed 10 May 2013]

3. Anchala R, Kannuri NK, HiPant H, Franco OH, Angelantonio ED,Prabhakaran D Hypertension in India: a systematic review and meta-analysis of prevalence, awareness, and control of hypertension. 2014 Jun; 32(6):1170-1177. doi: 10.1097/HJH.0000000000000146.

4. Chakraborty R, Bose K, Kozieł S. Waist circumference in determining obesity and hypertension among 18-60 years old Bengalee Hindu male slum dwellers in Eastern India. Ann Hum Biol. 2011;38:669-675.

5. Anand MP. Prevalence of hypertension amongst Mumbai executives. J Assoc Physicians India. 2000;48:12001201.

6. Kaur P, Rao TV, Sankarasubbaiyan S, Narayanan AM, Ezhil R, Rao SR, Gupte MD. Prevalence and distribution of cardiovascular risk factors in an urban industrial population in south India: a cross-sectional study. J Assoc Physicians India. 2007;55:771-776.
7. Reddy KS, Prabhakaran D, Chaturvedi V, Jeemon P, Thankappan KR, Ramakrishnan L, Mohan BV, Pandav CS, Ahmed FU, Joshi PP. Methods for establishing a surveillance system for cardiovascular diseases in Indian industrial populations. Bull World Health Organ. 2006;84:461-469.

8. Mohan V, Deepa M, Farooq S, Datta M, Deepa R. Prevalence, awareness and control of hypertension in Chennai--The Chennai Urban Rural Epidemiology Study (CURES-52). J Assoc Physicians India. 2007;55:326332.

9. Shanthirani CS, Pradeepa R, Deepa R, Premalatha G, Saroja R, Mohan V. Prevalence and risk factors of hypertension in a selected South Indian population--the Chennai Urban Population Study.J Assoc Physicians India. 2003;51:20-27.Gupta AK, Negi PC, Gupta BP, Bhardwaj A, Sharma B. Isolated systolic hypertension among office workers in north Indian town. Ind J Com Med 2006;31:109-10.

10. Kaur P, Rao TV, Sankarasubbaiyan S, Narayanan AM, Ezhil R, Rao SR, Gupte MD. Prevalence and distribution of cardiovascular risk factors in an urban industrial population in south India: a cross-sectional study. J Assoc Physicians India. 2007;55:771-776.

11. Midha T, Idris MZ, Saran RK, Srivastav AK, Singh SK. Prevalence and determinants of hypertension in the urban and rural population of a north Indian district. East Afr J Public Health. 2009;6:268-273.

12. Singh S, Shankar R, Singh GP. Prevalence and Associated Risk Factors of Hypertension: A CrossSectional Study in Urban Varanasi. International Journal of Hypertension 2017:1-10. https://doi.org/10.1155/2017/5491838.

13. Gupta R, Gupta VP, Sarna M, Bhatnagar S, Thanvi J, Sharma V, Singh AK, Gupta JB, Kaul V. Prevalence of coronary heart disease and risk factors in an urban Indian population: Jaipur Heart Watch-2. Indian Heart J. 2002;54:59-66.

14. Xu C, Sun Z, Zheng L, Zhang D, Li I, Zhang X, et al. Prevalence of and risk factors for isolated systolic hypertension in the rural adult population of liaoning province, China. J Int Med Res 2008;36:353-6. 